\title{
CORPORATIONS: ATTORNEY-DIRECTOR-OFFICER AS ALTER EGO OF UNDERCAPITALIZED CORPORATION
}

\begin{abstract}
As a concomitant of increased use of the corporate form of business, attorneys have developed a common practice of accepting positions as directors and officers in corporations which théy form. Since no active management is involved, these positions, normally accepted as a courtesy to the incorporator-client and as a convenience to the lawyer, are customarily labeled "dummy"1 or "accommodating." However, the law traditionally recognizes only the active, managing officer or director, ${ }^{3}$ whose duties and liabilities are substantially defined; ${ }^{4}$ special judicial
\end{abstract}

2 "In common parlance, 2 dummy director is one who is a mere figurchead and in effect discharges no duties." Golden Rod Mining Co. v. Bukvich, 108 Mont. 569, 572, 92 P.2d 3I6, 3 I9 (1939); accord, Ashby v. Peters, I28 Neb. 338, 341, 258 N.W. 639, 64I (1935) 3 Hoopes v. Basic Co., 69 N.J. Eq. 679, 61 Atl. 979 (I905).

In a close corporation, deprivation of management talent has no practical effect, since management by the entire board of directors is generally unwanted and avoided. See I O'Neai, Close Corporations \$§ 3.11-.39, 5.01-.39 (1958); O'Neal, Protecting Shateholders' Control Agreements Against Attack, 14 Bus. LAW. 184 (1958).

For reflections on the management functions of outside directors in large public issue corporations, see Weinberg, $A$ Corporation Director Looks at His Job, 27 HARV. Bus. REv. 585 (1949); see also Douglas, Directors Who Do Not Direct, 47 HARv. L. REV. 1305, 1314 (1934).

'See Henn, Corporations 187, 408 (I96I); Note, $A$ Defense of Non-Managing Directors, 5 U. CHr. L. REv. 668 (I938). Another title suggested for the advisor-type non-managing director is "consultant expert." See SAMUEL, SHAREHOLDERs' MONEY 124 (1933). Although the particular title used may vary, each is applicable, since the lawyer does not actively manage, but rather assumes the position for the special purpose of more easily supervising the legal aspects of his fledging corporate client during its first days of existence, and possibly even after it has grown to full maturity. Benefits to the corporation of this arrangement include primarily better legal services from its counsel and, in the case of some close corporations, safe storage for corporate books, records, and files.

3 "Theirs is not a mere position as sponsors or figurehead, devoid of responsibility." Ballantine, Corporations is6 (rev. ed. 1946). "A figurehead director is not tolerated in this country." I Hornstein, Corporation LaW aNd Practice 527 (1959). Accord, Golden Rod Mining Co. v. Bukvich, 108 Mont. 569, 92 P.2d 316 (1939); Ashby v. Peters, 128 Neb. 338, 258 N.W. 639 (1935); Hoopes v. Basic Co., 69 N.J. Eq. 679, 61 Atl. 979 (1905); People v. Central Fish Co., 117 App. Div. 77, IoI N.Y. Supp. I108 (1907); Hun v. Cary, 82 N.Y. 65 (1938); see also Douglas, supra note i; 5 U. CHI. L. Rev. 668 (1938); 82 U. PA. L. REv. 364 (1934). For a comparison with the English Companies Act of 1929, see Samuel, Shareholders' MONEY (I933); Douglas, supra note I; 5 U. CHI. L. REv. 668, 67I (1938).

- " 'Management' may be defined as that body of men who, in law, have formally assumed the duties of exercising domination over the corporate business and assets. . . . Universally, under the American system of law, managers consist of a board of directors 
treatment is seldom accorded non-managing officers or directors. ${ }^{5}$ Notwithstanding this traditional view, the accommodating attorney rarely considers the possible risks of personal liability implicit in his assumption of a courtesy position.

The California Supreme Court decision in Minton v. Cavaney ${ }^{6}$ should serve as a caveat for anyone serving in an accommodating or dummy capacity. In an action to enforce an unsatisfied wrongful death judgment recovered against an undercapitalized corporation, ${ }^{7}$ an attorney, ${ }^{8}$ claiming to have served only "in a temporary capacity as an accommodation," was found to be subject to liability as alter ego ${ }^{10}$ of and the senior officers of the corporation ...." BERLE \& MEANS, THE MODERN Corporation and Private Property 220 (i932). Some states have enacted statutes providing that directors shall be responsible for active management of corporate affairs. See, e.g., CAL. Corp. CODE § 800; N.Y. Gen. Corp. LAW § 27. However, "in the main, the rules of conduct applicable to managements were developed out of the common law and not out of statute . . ." BERLE \& MEANs, op. cit. supra at $22 \mathrm{I}$. See also Ballantine, Corporations 156-57 (rev. ed. 1946); Henn, Corporations

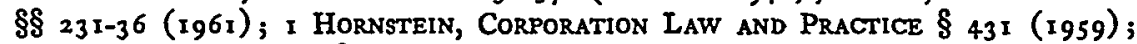
Stevens, CoRporations $§ 151$ (2d ed. 1949); Dwight, Liability of Corporate Directors, I7 Y ALE L.J. 33 (1907); Feuer, Liabilities of Directors and Officers, 5 N.Y.L.F. 127,235 (1959).

${ }^{8}$ But see Conaty v. Torghen, 46 R.I. 447, 453, I28 Atl. 338, 341 (1925), where 2 judgment on a directed verdict was reversed because it was well known that the defendant director-treasurer performed merely administrative functions, and therefore the jury should be allowed to consider his particular duties when determining liability. Cf. note 23 infra.

- 56 Cal. 2d 597, 364 P.2d 473 (196I).

- The Seminole Hot Springs Corporation had operated a public swimming pool which it had leased from its owner. Although the articles of incorporation provided for issuance of $\$ 700,000$ worth of capital stock, none was ever issued. Minton v. Kraft, I90 Cal. App. 2d 3 I1, —, I2 Cal. Rptr. 86, 88 (1961). Plaintiffs' daughter had drowned while swimming in the pool, and in a wrongful death action against Seminole, plaintiffs had recovered a $\$ 10,000$ judgment. Since the corporation was without capital, however, the judgment remained unsatisfied. 364 P.2d at 474 .

B Subsequent to the commencement of action in the instant case, the defendant attorney died and the executrix of his estate was substituted as defendant. Ibid. However, in this note "defendant" will refer to the deceased attorney whose acts served as the basis for litigation.

${ }_{364}$ P.2d at 475 .

${ }^{10}$ When a court pierces the corporate veil, it generally characterizes the individual defendant as a mere adjunct, agent, alter ego, cloak, cover, dry shell, tool, or other appropriate epithet suitable to the particular defendant. See LATTY, INTroduction To BUSIness Associations: Cases and Materials 42 (1951); i O'Neal, Close Corporations $\S 1.09$ (1958).

California previously adopted the alter ego characterization where "there is such a unity of interest and ownership that the individuality, or separateness, of said person and corporation has ceased, ... [ [and] the facts are such that an adherence to the fiction of separate existence of the corporation would ... sanction a fraud or promote injustice." 
the corporation.11 The supreme court dismissed defendant's "accommodation" contention by adopting the trial court's finding that he was, in fact, an active managing director, ${ }^{12}$ and by referring to a broad statute ${ }^{18}$ charging corporate directors with the responsibilities of management. Noting that defendant had not claimed to be "a director with specialized

Minifie v. Rowley, 187 Cal. 481, 487, 202 Pac. 673, 676 (1921). To support characterization of defendant as alter ego in the instant case, the court relied upon ( 1 ) the undisputed evidence that he was director, secretary, and treasurer of the clearly undercapitalized corporation; (2) the inference that he was equitable owner of corporate stock, based upon evidence that defendant, in his capacity as secretary of the corporation, had signed a petition requesting permission from the California Corporations Commissioner to issue three shares of stock, one of which he was to have received; and (3) the inference that he was an active participant in the conduct of corporate business, as demonstrated by storage of corporate records and receipt of corporate mail at defendant's law office. Although these findings may not strictly qualify to show "such a unity of interest and ownership" that the separateness of defendant and the corporation had ceased to exist, the court explained that "the figurative terminology 'alter ego' and 'disregard of the corporate entity' is generally used to refer to the various situations that are an abuse of the corporate privilege." $3^{6} 4$ P.2d at 475 .

${ }^{11}$ The most common instances where the corporate entity has been disregarded are where the corporation has been inadequately capitalized considering the magnitude and nature of its activities; where money, assets, equipment, and employees of two corporations have been intermingled; where none of the corporate formalities have been followed; and where there has been a holding out by the individual participants that they are personally liable for corporate operations. See generally Ballantine, Corporations $\$ 122$ (rev. ed. 1946); I Fletcher, Cyclopedia of Corporations \$§ 4 1-47 (perm. ed. 1931, Supp. 1961); Henn, Corporations 203 (1961); Horowitz, Disregarding the Entity of Private Corporations, pt. 1, 14 WASH. L. REv. 285 (1939), pt. 2, I 5 WASH. L. REv. I (1940); Fuller, The Incorporated Individual: $A$ Study of The One-Man Company, 51 HARV. L. REv. 1373, 1402 (1938). For the classic statement as to when the corporate veil will be pierced, see Sanborn, J., in United States v. Milwaukee Refrigerator Transit Co., 142 Fed. 247, 255 (C.C.E.D. Wis. 1905).

${ }^{12}$ The supreme court thus vacated the district court of appeal's decision. The latter court had found that defendant's acts merely constituted practicing law, since "the evidence at most shows only a course of conduct consistent with the role of an attorney in the formation and organization of a corporation." Minton v. Kraft, 19o Cal. App. 2d $311,-, 12$ Cal. Rptr. 86, 95 (1961). In reinstating the trial court's findings of fact, the supreme court said, "the trial court was not required to believe his [de. fendant's] statement that he was only a 'temporary' director and officer 'for accommodation.' In any event it merely raised a conflict in the evidence that was resolved adversely to defendant." $36_{4}$ P.2d at 475 . The dissenting opinion felt constrained to call attention to the different result which would have been reached if the evidence had shown defendant had merely been organizing the corporation. 364 P.2d at 477 .

13 "[A]1l corporate powers shall be exercised by or under authority of, and the business and affairs of every corporation shall be controlled by, a board of not less than three directors." CAL. CORP. CODE $\$ 800$. The corporation in the instant case had only three directors; thus, even if defendant had been found to have been an accommodating director, he still would have been subject to liability by statute as a managing director. 
duties, ${ }^{\prime 14}$ the court found him subject to liability on the basis of the general rule that once the corporate fiction has been disregarded, ${ }^{15}$ the equitable owners of an undercapitalized corporation are severally responsible for liabilities of the corporation. However, the court reversed the case for relitigation on the issue of corporate negligence, since defendant had not been a party to the previous action. ${ }^{10}$

Implicit in the holding in Cavaney was the court's recognition and approval of pre-business "paper positions" assumed by strawmen solely to effect compliance with required incorporation procedures. It is judicially well established that an attorney in organizing a corporation may initially hold "accommodation" offices, receive qualifying shares of stock, and perform any of the numerous functions necessary to organization without assuming officer or director liability. ${ }^{17}$ As a result, in recent years the statutory requirements for incorporation have been mechanistically followed with only slight regard for the purposes of such requirements. Positions of incorporators and initial directors have been regarded merely as part of the ritual of corporate organization and have not been taken seriously. Accordingly, no longer does the incorporator regard himself as a sponsor of the proposed corporate idea, nor does the initial "paper director" feel a responsibility to superintend the birth of the corporation on a sound basis.

The judicial approval accorded the use of strawmen suggests that the degree to which obligations in each stage of statutory incorporation

\footnotetext{
${ }^{14}{ }_{364}$ P.2d at 475 .

${ }^{15}$ Automotriz del Golfo de California S. A. de C. V. v. Resnick, $47 \mathrm{Cal}$ 2d 792, 306 P.2d I (1957); Annot., 63 A.L.R.2d 1051 (1959). See also Ballantine, Corporations 302-03 (rev. ed. 1946); LATTIN, Corporations 68-72 (1961); Frey, Legal Analysis and The "De Facto" Doctrine, 100 U. PA. L. REv. 1153, 1176 (1952), where the author found that tort actions against individual defendant participants are virtually certain to succeed. But cf. Moe v. Harris, 142 Minn. 442,172 N.W. 494 (1919), where no contract liability was imposed upon individual participants despite the fact that no capital stock had ever been paid in or even subscribed.

${ }^{10} 364$ P.2d at 476 ; RESTATEMENT, JUDGMENTS $\$ 84$, comment $e$ (1942). Plaintiffs had selected the alter ego theory in an attempt to hold defendant liable without relitigating the claim, thereby avoiding the effect of the statute of limitations which had run against the defendant. The net effect of reversal will be, therefore, to allow defendant to avoid liability by pleading the statute of limitations in any subsequent litigation against him.

${ }^{17}$ Recognition of the use of strawmen by the courts is well established. See Kardo Co. v. Adams, 231 Fed. 950 (6th Cir. 1916); Irvine Co. v. Bond, 74 Fed. 849, 852 (C.C.S.D. Cal. 1896); Donovan v. Purtell, 216 Ill. 629, 75 N.E. 334 (1905); State v. Miner, 233 Mo. 312,135 S.W. 483 (1911). See generally Henn, Corporations 187-89, 408 (1961); I HoRnstein, CoRporation LAW AND PRACTICE $\$ \S 134,135$ (1959, Supp. 1961); 1 Oleck, MODERN CoRporation LAW \$\$ 179, 521 (1958).
} 
should be imposed on the participating parties might well be reviewed by state legislatures. Some modern incorporation statutes have partially solved this situation by reducing the number of incorporators and eliminating paper directors in the incorporation process. ${ }^{18}$ Hence the truly interested parties tend to be revealed at the outset, and there is seldom a "paper transfer" of corporate interest prior to beginning business. These statutes do not, however, prohibit use of dummy incorporators or guarantee that the corporation will not be undercapitalized or defective in some other respect. Perhaps state legislatures should consider enacting statutes requiring the organizing parties to sponsor the corporate idea in fact as well as in form, and assuring that the newly formed entity is not a mere shell..$^{19}$

Though, at present, the lawyer may serve as a dummy incorporator and paper director, once the corporation has begun to engage in business, the attorney must turn over his offices to the real parties in interest and divest himself of all other vestiges of active participation. ${ }^{20}$ By retention of office beyond the period of organizational formalities, the attorney becomes a managing participant subject to all the duties and liabilities of his position. Thus, by extending accountability for corporate management to all officers and directors, the law tends to encourage and enforce responsible participation. ${ }^{21}$

${ }^{18}$ See, e.g., DEL. CODE ANN. tit. 8, $§ \S 101,102$ (1953) (no requirement that initial directors be named, but at least three incorporators must sign the articles of incorporation); IOWA CODE ANN. $\$ 491.2$ (Supp. 196r); KY. REv. STAT. § 271.055 (Supp. 1960); Mich. COMP. LAWS $\$ 450.3$ (Supp. 1956); N.Y. Bus. CoRp. LAW $\S \$ 401,404$ (not effective until April $x, 1963$ ); WIs. STAT. $§$ r80.44 (1957); see also HENN, Corporations $\$ \S 129,130$ (1961); I HoRnstein, Corporation LAW AND PRACTICE \$§ 134, 135 (1959, Supp. 1961); I OlECK, MOdern CoRporation LaW \& 179 (1958); Latty, Powers, \& Breckenridge, The Proposed North Carolina Business Corporation Act, 33 N.C.L. REv. 26 (1954); Luce, Trends in Modern Corporation LegisLation, 50 Mich. L. REv. 1291 (1952); Rutledge, Significant Trends in Modern Incorporation Statutes, 22 WAsH. U.L.Q. 305 (1937).

${ }^{10}$ Local bar associations also might consider sanctioning those attorneys who knowingly organize defective corporations.

"If the statutory process for incorporation requires "paper meetings" of the incorporators and board of directors, appropriate resignations are customarily tendered before such meetings. If no formal meetings are required, as is the case in some modern incorporations statutes, turnover is normally effected at a similarly appropriate time before the business begins to function as a mature corporate entity. Sec HenN, CoRporations $187-89,408$ (1961); I Hornstein, CoRporation LAW and Practice $\S \S 134,135$ (1959, Supp. 1961); 1 OLECK, Modern Corporation Law $\S$ 179, 521 (1958).

${ }_{21}$ 'Prominent men cannot safely lend their names as directors for the sake of prestige and advertising value to the company, upon an understanding that they need not take any part in management and supervision." Ballantine, Corporations, r56 (revivi ed. 
Tempering this general rule of participant accountability, however, there has been some support for legal recognition of the non-managing director.22 Moreover, varying degrees of individual liability occasionally may be inferred from the apparent reluctance of some courts to impose the full burdens of personal liability equally upon all directors and officers. ${ }^{23}$ Indeed, an aspect of this reluctance may be reflected in the instant case. By specifically noting that defendant did not claim to be "a director with specialized duties,"24 the court implied that an attorney, who continues to serve as a director after the corporation is engaging in business but who confines his activities solely to consultation on and handling of the legal aspects and problems of the corporation, might be vindicated from personal liability provided he had not been derelict in his specialized duty.

The dearth of cases involving attorneys acting as directors and offcers $^{26}$ indicates that the characteristics of such non-managing participation will be seldom litigated. Consequently, the busy lawyer may feel

1946); accord, Dwight, supra note 4. For a critical treatment of the titled nonmanaging directors under the British Companies Act and a novel suggested solution, see SAMUEL, Op. cit. stpra note 2, at II 1-24.

${ }^{23}$ See Stevens, Corporations 646-56 (2d ed. 1949); Douglas, supra note I, at 1332-14; Dwight, supra note 4. For the special situation of the investment banker, see BrandeIs, Other People's MONey (1953); and concerning the "business connection" bank director, see Berle \& Means, The Modern Corporation and Private Property 231 n.I6 (1932).

"See Bates v. Dresser, 251 U.S. 524 (1920) (bank president held liable for failure to discover embezzlement by employee, while directors were vindicated); Barnes v. Andrews, 298 Fed. 614 (S.D.N.Y. 1924) (receiver of insolvent corporation had not satisfied the burden of showing that defendant director could have prevented corporate insolvency); Allied Freightways v. Cholfin, 325 Mass. 630, 93 N.E.2d 765 (1950) (wife who was dummy director of insolvent trucking company excused from liability for mismanagement when her husband wrongfully disbursed corporate funds in the exercise of his office as president); Wallach v. Billings, 277 Ill. 218,115 N.E. 382 (1917) (non-resident director of Chicago bank exonerated from liability since his sole function was as an out-of-state "contact" agent). See also BAKER \& CARY, CAsEs AND Materials on Corporations 393-416 (3d ed. abr. 1959); Cushing, The Liability of The Inactive Corporate Director, 8 Colum. L. REv. 18 (1908). For a concise summary of flexible liability standards, see 5 U. CHI. L. REV, 668, 671-72 (1938).

${ }^{24} 364$ P.2d at 475 .

${ }^{25}$ Research has failed to reveal any cases turning on the question of whether an accommodating attorney who is a non-managing officer or director of a corporation which is already engaging in business will be given special judicial protection from individual liability. The decision in the instant case, however, clearly settles the law in California that an attorney acting as a non-managing accommodating director is included within the scope of the statute imposing duties and liabilities of active management upon the directors of a corporation. See 364 P.2d at $475-76$; note 13 supra. Concerning imposition of liability, see note 23 supra. 
that the inconveniences of the suggested approach outweigh the benefits to be realized and conclude that an expenditure of his time is not warranted. The Cavaney case, however, dramatically demonstrates that the lawyer may be subject to considerable risk of personal liability. Thus efforts to preclude such liability clearly merit serious consideration. Close scrutiny of corporate legal affairs by the attorney seems reasonable as a fair price for the convenience and protection afforded by a specialized duties position. ${ }^{28}$

The holding in and the implications from Cavaney suggest that a lawyer should determine whether the courts of his state might recognize any position similar to the specialized duties director. If there are either no indications or only unfavorable implications relative to state judicial recognition of such positions, and if the risk of liability is considerable, perhaps the attorney should consider refusing to "accommodate" after completion of organizational formalities, even at the prospect of losing a client. However, if initial determinations support a reasonable inference that special treatment may be afforded, the lawyer should then balance the responsibilities of active legal supervision he would have to assume against the benefits he would derive from such a position. Until the courts and legislatures establish more explicit bases, perhaps common sense and personal experience, coupled with a through investigation of the relevant factors, are the best guide lines available.

\footnotetext{
${ }^{20}$ See Weinberg, supra note 1.
} 